\title{
Weekend Services at Hospital: A Case Study of the Cardiovascular Harapan Kita Hospital-Indonesia
}

\author{
Irfan Arief \\ Magister Management, Faculty of Economics and Business, University of Mercu Buana, \\ Indonesia
}

\begin{abstract}
M. Noor Salim (Corresponding author)
Faculty of Economics and Business, University of Mercu Buana, Indonesia

E-mail: m_noorsalim@yahoo.com
\end{abstract}

Received: June 7, 2017 Accepted: June 13, 2017 Published: June 30, 2017

doi:10.5296/bms.v8i1.11367 URL: https://doi.org/10.5296/bms.v8i1.11367

\begin{abstract}
This study aims to determine the effect of the product, physical evidence, people towards healthy motivation and the patient's decision. In this study, data collection was conducted through survey method by distributing questionnaires to patients of Weekend Service at the Cardiovascular Harapan Kita Hospital-Indonesia. The number of samples taken in this study was 133 patients. The sampling technique used in this study was simple random sampling. The model analysis used Structural Equation Modeling (SEM). The results showed that the variable data processing product, physical evidence, people influence the patient's decision through a healthy motivation. Parameter estimation for testing the effect of the product on the motivation of healthy showed the CR value of 1.994 ( $\mathrm{p}=0.046)$. The effect of the physical evidence on the motivation of healthy showed the CR value of 2.762 ( $p=0.006)$. The influence of people on the motivation of healthy showed the CR value of 2.629 ( $p=0.009)$, and a healthy motivational influence on the decision CR patients showed values of $2.005(\mathrm{p}=$ 0.045).
\end{abstract}

Keywords: Product, Physical evidence, People, Healthy motivation, Patient decision 


\section{Introduction}

The growing and a better economic equality will increase the needs and demands of society for quality health services and affordable in accordance with the ability of the community. Law No.23 of 1992 also explains that "Health services are still citizens' rights". But the right here does not mean that it is free, but it can mean that health services are available, accessible, of good quality, and at the price paid by all levels of society. The management of health facilities is required to be managed with modern management and is socio-economic. Providers of Public Health Services, whether Primary, Secondary and Tertiary levels should always respond to changes that occur quite quickly and then immediately anticipate in accordance with the wishes and needs of the community who currently require the health services that are easy, fast and comfortable, which in the end can provide satisfaction in the results of treatment in accordance with the disease he/she suffered. Therefore, the Cardiovascular Harapan Kita Hospital-Indonesia as National Referral Hospital (Tertiary Hospital) is increasingly demanded to provide better health services for the community especially providing heart and blood vessel services as its core service. Based on the guarantor, currently the Cardiovascular Harapan Kita Hospital-Indonesia opens 2 types of services consisting of Services with BPJS guarantee and Service with a guarantee of Non-BPJS. Both services are based on implementing a good Service Quality Management. It is proven with the certification of the Hospital Accreditation Committee (KARS) by 2015 and Join Commission International (JCI) in 2016.

There are some obstacles faced by the Cardiovascular Harapan Kita Hospital-Indonesia along with its achievements so far. Being a National Referral Hospital is not an easy matter because the Cardiovascular Harapan Kita Hospital-Indonesia must be able to serve its patients from all over the country well. The Cardiovascular Harapan Kita Hospital-Indonesia should continue to think and spur the institution not only to conduct curative treatment efforts, but must actively undertake preventive efforts through the Hospital Health Promotion Program (PKRS) by providing education of heart health to the public for higher health status and at the same time Minimizing the burden of the state to finance the health of its citizens. Some of the obstacles faced by the Cardiovascular Harapan Kita Hospital-Indonesia and the way out in carrying out its services at this time, among others: Infrastructure is no longer relevant to the existing conditions, the need for higher heart specialist doctors and financial burden. The financial burden is an issue that must be overcome. This financial burden arose from the difference between INA-CBGs tariff and the Cardiovascular Harapan Kita Hospital-Indonesia's tariff. This is what makes this research gap. To cover this financial burden the Cardiovascular Harapan Kita Hospital-Indonesia should think about how to obtain new revenue sources and the results can be used as a source of cross subsidy to cover the treatment and actions not included in the BPJS financing. One of the efforts made to obtain a new source of income since 2000 the Cardiovascular Harapan Kita Hospital-Indonesia opened the executive service in the form of Executive Polyclinic and Executive Inpatient. Along with its development, to supplement its income to provide cross subsidy for patients in need, in March 2015, the Cardiovascular Harapan Kita Hospital-Indonesia launched a service 
product called "Weekend Service", which targeted executives but still prioritizes the social marketing concept that addresses the needs, The desires and interests of the patient and provide the desired satisfaction in a more effective and efficient way, while maintaining a balance between the three considerations in determining the marketing policy of the Cardiovascular Harapan Kita Hospital-Indonesia, namely: Profit (as cross-subsidizing capital), satisfaction of the wants and needs of the patient and the public interest. Aside from being a source of cross-subsidies, this Weekend Service product is also proclaimed as an effort to assist the government in reducing the foreign exchange burden that overseas resulting from many patients from Indonesia who seek treatment abroad.

Since its launch in early March 2015, the product of this service immediately gets a good response from the public, especially people with personal guarantees. Looking at existing data, it is assumed that there is a good potential of this Weekend Service product to be developed, especially in the marketing aspect, so that able to move the willingness of patients who have the ability to pay to be able to entrust their heart disease treatment to the Cardiovascular Harapan Kita Hospital-Indonesia and do not go abroad. In this case, there are two advantages that will be at once, that is, not to dispose of foreign exchange and increase the income of the Cardiovascular Harapan Kita Hospital-Indonesia as cross-subsidized capital for patients in need.

This research is aimed to study, analyze, and know in detail about the effect of Product, Physical Evidence, People (exogenous variables) on healthy motivation (endogenous variable mediation) and patient decision (endogenous variable). The research question is to know and analyze: (1) the influence of Product on Healthy Motivation, (2) Physical Evidence influence to Healthy Motivation, (3) People influence on Healthy Motivation, (4) Product influence on Patient Decision, (5) Influence of Physical Evidence on Decision of Patient, (6) People influence on Patient Decision, (7) influence of Healthy Motivation to Patient Decision. This research will be limited by the following aspects: (1) The variables of this study are limited to only 5 (five) variables, namely: Product, Physical Evidence, People, and Healthy Motivation influence Patient Decision, so the focus of the study is only to the extent of the five variables. (2) The location of the study is only at the Cardiovascular Harapan Kita Hospital-Indonesia in the scope of Weekend Service, so the results cannot be automatically generalized to other hospitals. (3) The timing of the study is not periodic (time-series), but is cross-sectional, so this study also has time constraints. (4) The respondents in this study were restricted to patients of the Weekend Service product period of the Year 2015. This study is useful (1) As an information about the effect of the variables that influence the patient's decision in choosing Weekend Service product, (2) As a consideration for policy makers at the Cardiovascular Harapan Kita Hospital-Indonesia to determine the next strategic step in optimizing its service, (3) As a consideration for Installation of Marketing and Customer Service in making marketing and sales strategy in increasing revenue of Weekend Service, 4) As a consideration for the Cardiovascular Harapan Kita Hospital-Indonesia in winning market competition, both local, regional and international, as a consideration for the Cardiovascular Harapan Kita Hospital-Indonesia to assist and minimize the burden of 
government to finance public health, and

\section{Literature Review}

Purchasing Decision. According to Schiffman and Kanuk (2007), a decision is the selection of two or more alternative options. Alternative choices must be available to a person when making decisions. According to Kotler and Keller (2012), consumer buying behavior is influenced by several factors, including: (1). Cultural factors that include subculture and social class. (2). Social factors that include reference groups, families and roles and status. (3). Personal factors, that include age, occupation, personality and style, and values, (4). Psychological factors that include perception, learning, and memory. Thus, post-consumer purchasing scores "provide feedback" such as experience with consumer psychology and help influence future decisions. In simpler terms, Kotler and Keller (2012) summarized the stages of consumer purchasing decisions divided into five stages: (1) Introduction of needs, (2) Information search, (3) Alternative Evaluation, (4) Purchasing decision, (5) Post purchase behavior. As the theories about purchasing decisions that have been described above, the authors determine the dimensions included in this study is based on Kotler and Keller (2012), including: (1) $\eta 2.1=$ Introduction of Needs; (2) $\eta 2.2=$ Information Search; (3) $\eta 2.3=$ Alternative Evaluation; (4) ๆ2.4 = Patient Decision; (5) ๆ2.5 = Post-Purchase Behavior.

Product. The product is everything that is offered both tangible and intangible to the market to get the attention, purchased, used and that can satisfy the desire or the needs of the consumer including the packaging, color, price, quality, and brand plus the service and sales reputation (Kotler \& Armstrong, 1996). According to the American Society for Quality Control, the quality is: "The totality of features and characteristics of a product or service that bears on its ability to satisfy given needs". This means the overall characteristics and characteristics of a product or service that demonstrate its ability to satisfy the implied needs. This definition is a quality-centered definition of the consumer so it can be said that a seller has provided quality when the product or service seller has met or exceeded consumer expectations the product is an understanding that the product offered by the seller has more selling value that is not owned by the competitor's product. Therefore the company tries to focus on product quality and compare it with the products offered by the competitor company. However, a product with the best performance or even a better look is not the highest quality product if it is not what the market wants and wants. According to Kotler and Armstrong (1996), the meaning of product quality is: "The ability of a product to perform its functions, it includes the product's overall durability, reliability, precision, ease of operation and repair, and other valued attributes". Several studies have been conducted on products and satisfaction, including Motwani, Shrimali, and Agarwal (2014) and Zarchi et al (2014) indicated that product quality has a positive effect on customer satisfaction. Further, Armen, Sefnedi, and Yuhelmi (2013) explained that variables in the marketing mix (product, price, promotion, location, and personnel) have a positive and significant effect on purchasing decisions.

Product Quality Dimensions. Product quality dimensions according to Lupiyoadi and 
Hamdani (2006): "Consumers not only buy the physical from the product but the benefits and value of the product called" the offer". The excellence of service products lies in its quality, which includes reliability, responsiveness, certainty, and empathy. Based on the results of the study of several theories about the above products, the most relevant theory for the determination of dimensions in this study is based on what is delivered by Lupiyoadi and Hamdani (2006), namely: (1) $\xi 1.1=$ Reliability; (2) $\xi 1.2=$ Responsiveness; (3) $\xi 1.3=$ Certainty / Assurance; (4) $\xi 1.4=$ Empathy.

Physical Evidence. According to Lovelock cited in Hurriyati (2010) stated that the company through its marketers uses three ways to manage the physical evidence of the strategy, as follows: (1) An attention-creating medium, service companies differentiate with competitors and create means Physically as attractive as possible to capture customers from its target market. (2) As a message-creating medium, using symbols or cues to communicate intensively to an audience about the specificity of the quality of the service product. (3) An effect-creating medium, colorful uniforms, patterned, sound and design to create something other than the products offered services. According to Zeithaml and Bitner in Hurriyati (2010) explained that services are intangible (intangible), making it difficult to evaluate. Physical evidence provides tangible signs and can be used to evaluate services. Physical evidence includes all tangibles regarding services such as building, exterior and interior design of the bank, modern bank equipment, tidiness of placement of brochures, forms, and pamphlets, the convenience of the waiting room of the bank and the cleanliness of banks and bathrooms. Physical evidence includes facility design, signage, and equipment. Lupiyoadi and Hamdani (2006) explained that: "Physical evidence is a physical environment where services are created and directly interact with consumers". There are two types of physical evidence, namely: (1) Important evidence. It is a decision made by the service provider regarding the design and layout of the building, space, etc. (2) Supporting evidence. It is a plus that when standing alone will not mean anything. So, it only serves as a complement, but its role is very important in the process of service production. Example: airfare. Physical evidence helps marketers to position their companies on the market and provide real or even location-related support. Prior research conducted by Motwani, Shrimali, and Agarwal (2014) gave results that physical evidence had a positive effect on satisfaction. In addition to the two types of physical evidence above, the researcher added one more dimension of the other evidence of publication about RSJPDHK in various media. Based on the results of the study of several theories about Physical Evidence above, the most relevant theory for the determination of dimensions in this study is based on what is delivered by Lupiyoadi and Hamdani (2006) which consists of: (1) $\xi 2.1=$ Important Evidence; (2) $\xi 2.2=$ Supporting evidence; (3) $\xi 2.3=$ Other Evidence.

People. According to Zeithaml and Bitner which cited in Hurriyati (2010) understanding, people are as follows: "People are all actors who play a role in the presentation of services that can affect buyer's perception. The elements of 'people' are employees of companies, consumers, and other consumers in the service environment. All attitudes and appearances of employees have an influence on consumer perceptions or service delivery success (service 
encounter)". The service marketing which relates to the role of people or people is very important. Especially if the product is dominated by the service charge. So that element of service and performance become the measure of service quality. Persons involved in marketing may come from corporate or management leaders, employees or staff, and the customer. They have different roles in marketing activities. Not only as a provider and provider of services. But their existence is part of a marketing system. So one with the other mutually supports and complement. Later can support marketing activities, especially marketing that is internal (Internal Marketing). For that required the existence of quality resources than the role of education, training, motivation is needed. People or people according to Zeithaml and Bitner cited in Hurriyati (2010) are all actors who play a role in service delivery and influence buyer's perception. People or People are recruited and trained employees who are capable and reliable in dealing with customers in delivering such services (Capability Development Program). The people dimensions are Skill, Education, and Knowledge. Motwani, Shrimali and Agarwal (2014) and Zarchi et al., (2014) found that people have a positive effect on satisfaction.

\section{Research Methodology}

\subsection{Data and Variables}

The design of this research uses explanative research method. Explanative research is a study that aims to test various hypotheses whose purpose is to justify or reinforce the hypothesis and determine the nature of the relationship between one or more exogenous variables with one or more endogenous variables. The authors limit the scope of this study to the application of product variables $(\xi 1)$, Physical Evidence $(\xi 2)$ and People ( $\xi 3)$ as exogenous, Healthy Motivation $(\eta 1)$ as endogenous mediation/intervening variables, and Patient Decisions ( $\eta 2)$ as endogenous variables. The study was conducted at the Cardiovascular Harapan Kita Hospital-Indonesia for its Weekend Service, which is located at Jl. Lieutenant General S. Parman Kav. 87, Slipi, West Jakarta.

This research uses five variables, namely: Product, Physical Evidence, People, Health Motivation and Patient Decision. Product ( $\xi 1)$; it is the concept of an object or process that delivers value to the consumer. Noteworthy in the product is the consumers not only buy the physical from the product alone but by the benefits and value of the product called "The Offer." The dimensions of this variable include Reliability, Responsiveness, Certainty, and

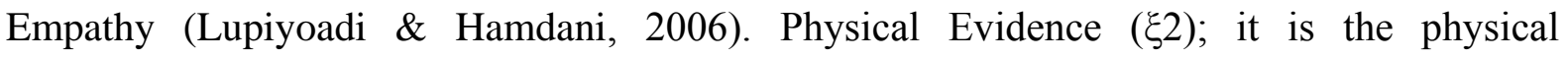
environment where services are created and directly interact with consumers. The dimensions of the variables include: Important Evidence and Direct Evidence and supplemented with other Evidence (Lupiyoadi \& Hamdani, 2006). People ( $\xi 3)$; it is all actors who play a role in service delivery and influence buyer perceptions. People or People are recruited and trained employees who are capable and reliable in dealing with customers in delivering services. The dimensions of this variable include Skill, Education, and Knowledge (Nirvana, 2012). Healthy motivation $(\eta 1)$; it is a variable that is defined as a reflection of people who are willing to do something for their own health and ready to carry out actions or actions that 
nourish his body. The dimensions of this variable include Emotion, Health Status, and Trust in Brand. Patient Decisions ( $\eta 2$ ); it is a decision to select two or more alternatives. Alternative choices must be available to a person when making decisions. The dimensions of this variable include: Needs Introduction, Information Search, Alternative Evaluation, Purchase Decision and Postpartum Behavior (Schiffman \& Kanuk, 2007). Table 1 specifies the variables in detail with its indicators.

Table 1. Variables Summary

\begin{tabular}{|c|c|c|}
\hline Variables & Dimensions & Indicators \\
\hline \multirow[t]{4}{*}{ Product ( $\xi 1)$} & Reliability ( $\xi 1.1)$ & - Timeliness of services \\
\hline & Responsiveness ( $(1.2)$ & - Responsiveness and promptness \\
\hline & Certainty $(\xi 1.3)$ & - Certainty \\
\hline & Empathy ( $\xi 1.4)$ & - Attention and sincerity \\
\hline \multirow{3}{*}{ 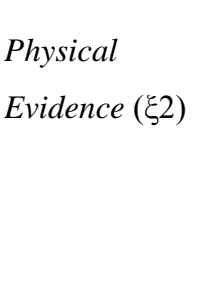 } & Importance proof $(\xi 2)$ & - Facilities and infrastructure \\
\hline & Supporting proof $(\xi 2)$ & - Legality and certification \\
\hline & Other proof $(\xi 2)$ & - Publicity \\
\hline \multirow[t]{3}{*}{ 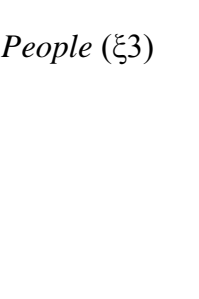 } & 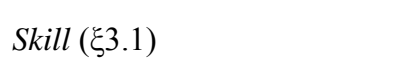 & - Skills \\
\hline & Education ( $(\xi 3.2)$ & - Education level \\
\hline & Knowledge (乡3.3) & - Knowledge \\
\hline \multirow{3}{*}{$\begin{array}{l}\text { Motivation } \\
\text { for health } \\
(\eta 1)\end{array}$} & Emotion $\quad(\eta 1.1)$ & - Safe and comfort \\
\hline & Health status ( $\eta 1.2)$ & - Healing rate and health status \\
\hline & Brand trust $(\eta 1.3)$ & - Trust in hospital \\
\hline \multirow{2}{*}{$\begin{array}{l}\text { Patient's } \\
\text { decision ( } \eta 2)\end{array}$} & Identification of needs ( $\eta 2.1)$ & - Health condition \\
\hline & Information search $(\eta 2.2)$ & - Information seeking about the hospital \\
\hline
\end{tabular}


Alternative evaluation ( $\eta 2.3)$

Patient's decision $(\eta 2.4)$

Post purchase behavior ( $\eta 2.5)$
- Credibility and price of services

- Suitability of needs

- Return control and recommendation

The measurement scale used in this research is Likert scale. The population in this study was the patient of Weekend Service during the period 2015 to the number of 174 patients. Using the Slovin formula to determine the number of samples in this study, the sample used was 133 respondents. The sampling technique used was Probability Sampling method, that is sampling technique that gives equal opportunity for each element (member) of the population to be selected become a member of the sample. The type used is Simple Random Sampling which is a method of sampling from members of the population randomly without regard to the strata (levels) that exist in members of that population.

\subsection{Model Analysis}

The data analysis method used is the SEM (Structural Equation Modeling) analysis of the AMOS statistical package. Some steps to be followed in the complete modeling model (Ferdinand, 2002: 34), namely: (1) Development of the theory-based model. (2) Development of the flow diagram (Path diagram). (3) Convert the flowchart into the equation. (4) Selecting input matrix and model estimation. (5) Anticipate the emergence of the problem of identification (6) Evaluation criteria Goodness of fit (conformity test).

\section{Structural equations model:}

$$
\begin{aligned}
& \eta 1=\xi 1+\xi 2+\xi 3+\zeta \\
& \eta 2=\xi 1+\xi 2+\xi 3+\eta 1+\zeta \\
& \eta 2=\eta 1+\zeta
\end{aligned}
$$

(measurement model)

$$
\begin{array}{llll}
\xi 1.1=\lambda 1+\varepsilon 1 & \xi 2.2=\lambda 6+\varepsilon 6 & \eta 1.1=\lambda 11+\varepsilon 11 & \eta 2.2=\lambda 15+\varepsilon 15 \\
\xi 1.2=\lambda 2+\varepsilon 2 & \xi 2.3=\lambda 7+\varepsilon 7 & \eta 1.2=\lambda 12+\varepsilon 12 & \eta 2.3=\lambda 16+\varepsilon 16 \\
\xi 1.3=\lambda 3+\varepsilon 3 & \xi 3.1=\lambda 8+\varepsilon 8 & \eta 1.3=\lambda 12+\varepsilon 13 & \eta 2.4=\lambda 17+\varepsilon 17 \\
\xi 1.4=\lambda 4+\varepsilon 4 & \xi 3.2=\lambda 9+\varepsilon 9 & \eta 2.1=\lambda 14+\varepsilon 14 & \eta 2.5=\lambda 18+\varepsilon 18 \\
\xi 2.1=\lambda 5+\varepsilon 5 & \xi 3.3=\lambda 10+\varepsilon 10 & &
\end{array}
$$

(measurement model) 


\section{Findings and Discussion}

The structural equation generated by the fit model (full model) on standardized regression weights as follows:

Table 2. Standardized Regression Weights Structural Equations Model

\section{Estimate Structural Error}

\begin{tabular}{|c|c|c|c|c|}
\hline Motivation-Health & $<---$ & Product & 0,249 & \\
\hline Motivation-Health & $<---$ & Physical Evidence & 0,334 & e $19(0,066)$ \\
\hline Motivation-Health & $<---$ & People & 0,306 & \\
\hline Patient's decition & $<---$ & Motivation-Health & 0,269 & e $20(0,089)$ \\
\hline Patient's decition & $<---$ & Product & 0,172 & \\
\hline Patient's decition & $<---$ & Physical Evidence & 0,145 & e $20(0,089)$ \\
\hline Patient's decition & $<---$ & People & 0,066 & \\
\hline
\end{tabular}

Based on the above table we obtain the following structural equations:

Structural equation 1: $\quad \boldsymbol{\eta} \mathbf{1}=\boldsymbol{\xi} \mathbf{1}+\xi \mathbf{2}+\xi \mathbf{3}+\zeta$

Motivation-Health $=\xi 10,249+\xi 20,334+\xi 30,306+\zeta 0,066$

Structural equation 2: $\boldsymbol{\eta} 2=\boldsymbol{\xi} 1+\xi 2+\xi 3+\eta 1+\zeta$

Patient's decision $=\xi 10,172+\xi 20,145+\xi 30,066+\eta 10,269+\zeta 0,089$

Structural equation 3: $\boldsymbol{\eta} \mathbf{2}=\boldsymbol{\eta} \mathbf{1}+\boldsymbol{\zeta}$

Patient's decision $=\eta 10,269+\zeta 0,089$

The effect of three variables of the marketing mix (product, physical evidence, and people) on the motivation for health. From the results of research that have been done, product, physical evidence, and people who are part of the marketing mix affect the motivation healthy. The estimation parameter for testing the effect of the product on healthy motivation showed CR value of 1.994 with a probability of 0.046 , physical evidence on healthy motivation showed CR value of 2.762 with a probability of 0.006 , and people on healthy motivation showed CR value of 2,629 with a probability of 0.009 . The results of research that complete the research conducted by Sarianti and Atris (2013), which in their 
research stated that two variables of the marketing mix that is promotion and distribution have a significant effect on consumer purchasing motivation. According to him, there are many influences underlying one's motivation in making purchases of a product or brand that must be learned by marketers, and not just the influence of marketing mix strategies imposed by marketers that affect consumers. In most people, consumer buying behavior is often initiated and influenced by the number of stimuli from outside himself, both in the form of marketing stimulus (in this study is the product, physical and other people) and stimuli from another environment. The stimuli are then processed within, according to their personal characteristics, before a purchase decision is finally made. Consumer personal characteristics used to process the stimulus is very complex, and one of them is the motivation of consumers to buy in this study is healthy motivation.

The effect of motivation on health on the patient decision. The estimation parameter for testing the influence of healthy motivation on the patient's decision shows CR value of 2,005 with probability equal to 0,045 . This explains that healthy motivation affects the patient's decision. Before deciding to use the services of Weekend Service at the Cardiovascular Harapan Kita Hospital-Indonesia, in addition to considering the three marketing variables included in this research are product, physical evidence, and people, patients are also encouraged by their belief that they feel safe and comfortable if they seek treatment in the Cardiovascular Harapan Kita Hospital-Indonesia (emotional dimension), they Believe that their healing and health status will increase (health status dimension), and they believe that the Cardiovascular Harapan Kita Hospital-Indonesia has a good reputation in handling heart disease (dimension of trust to the Cardiovascular Harapan Kita Hospital-Indonesia). This gives the understanding that before deciding to seek treatment, the patient is motivated to be healthy by considering the above three dimensions. This study reinforces research conducted by Danial MM in 2008 which explains that based on theoretical implications it turns out purchasing decision is significantly influenced by motivation. This is in line with what Kotler (2002) stated that the main factors affecting buying behavior are cultural factors, social factors, personal factors, and psychological factors. Psychological factors that can affect consumer buying behavior are motivation, learning, perception, and attitude. Similarly, Oktawinanda et al (2013) in his research concluded that motivation has a significant effect on purchasing decisions.

The effect of the three variables of the marketing mix (product, physical evidence, and people) on the purchasing decision. The estimation parameter for testing the effect of the product on the patient's decision shows CR value of 1,556 with probability equal to 0,120 . The estimation parameter for testing the effect of the physical evidence on the patient's decision shows CR value of 1.326 with a probability of 0.185 . The estimation parameter for testing the influence of people on the patient's decision shows CR value of 0.609 with a probability of 0,543 . This explains that the three variables have no effect on the patient's decision. Thus, this study contradicts Armen, Sefnedi, and Yuhelmi (2013) which explains that variables in the marketing mix (product, price, promotion, location, and personnel) have a positive and significant effect on purchasing decisions. This contradiction is possible 


\section{Macrothink}

because this research uses an intervening variable that is healthy motivation. According to him, purchasing decisions are generally influenced by various factors either individually or collectively, such as product or service, choosing the type, the determination of the time of purchase, or where to buy. Therefore it is important for the company to develop it. Determining prices, and distributing products and services, motivation and appropriate attitude to consumers is to use marketing mix strategy. The structural equation model is depicted in Figure 1.

Figure1. Structural Equation Model

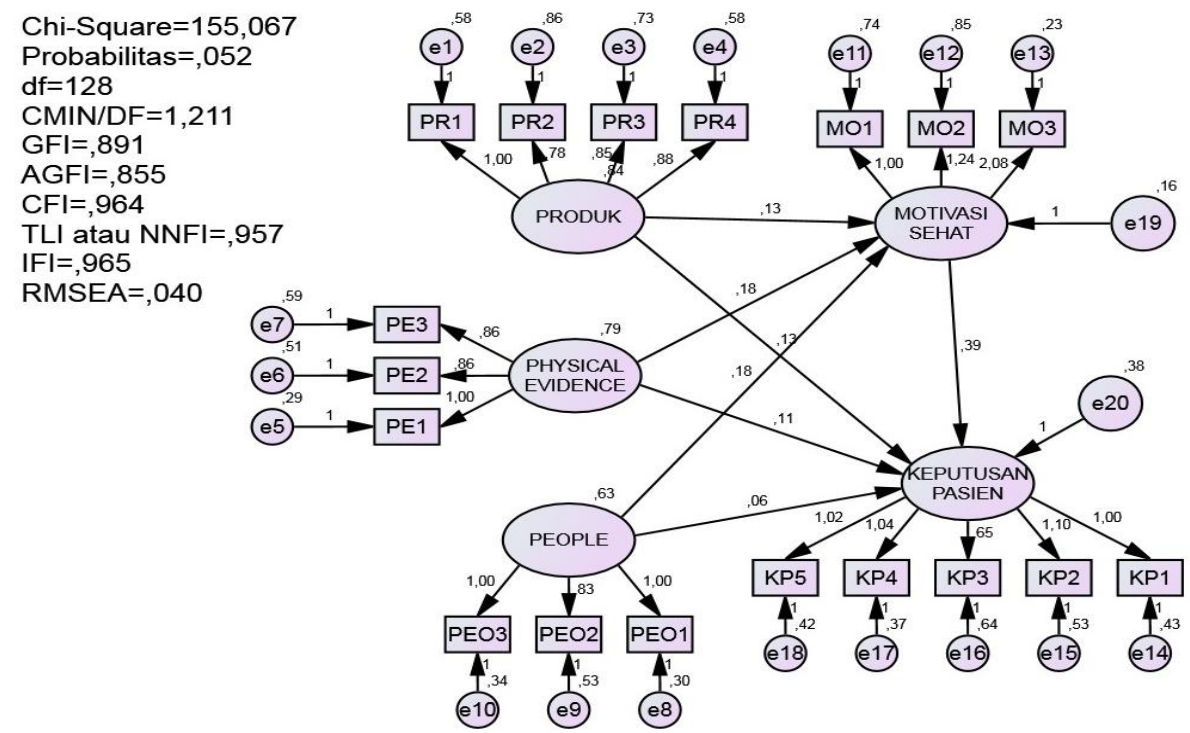

After all, assumptions can be met, then will be tested the hypothesis as proposed in the previous chapter. Testing 7 hypothesis of this research is based on Critical Ratio (CR) value of a causality relationship from SEM processing result as in Table 3 below.

Table 3. Regression Weight Structural Equational Model

\begin{tabular}{|c|c|c|c|c|c|c|c|}
\hline & & & Estimate & S.E. & C.R. & $\mathrm{P}$ & Label \\
\hline Motivation-Health & $<---$ & Product & 0,129 & 0,065 & 1,994 & 0,046 & par_1 \\
\hline Motivation-Health & $<---$ & Physical_Evidence & 0,178 & 0,064 & 2,762 & 0,006 & par_2 \\
\hline Motivation-Health & $<--$ & People & 0,183 & 0,070 & 2,629 & 0,009 & par_3 \\
\hline Patient's decision & $<---$ & Motivation-Health & 0,389 & 0,194 & 2,005 & 0,045 & par_4 \\
\hline
\end{tabular}




\begin{tabular}{lclccccc} 
& & Estimate & S.E. & C.R. & P & Label \\
\hline Patient's decision & $<--$ Product & 0,129 & 0,083 & 1,556 & 0,120 & par_5 \\
& & & & & & & \\
Patient's decision & $<---$ & Physical_Evidence & 0,112 & 0,085 & 1,326 & 0,185 & par_6 \\
& & & & & & & \\
Patient's decision & $<---$ & People & 0,057 & 0,094 & 0,609 & 0,543 & par_7
\end{tabular}

The estimation parameter for testing the effect of the product on healthy motivation shows CR value of 1,994 with probability equal to 0,046 . A CR value of 1.994 greater than 1.656 and a probability smaller than 0.05 explains that the product has a significant (real) effect on healthy motivation. The estimation parameter for testing the influence of physical evidence on healthy motivation shows CR value of 2,762 with probability equal to 0.006 . A CR score of 2.762 greater than 1.656 and a probability smaller than 0.05 explains that physical evidence has a significant effect on healthy motivation. The estimation parameter for testing the influence of people on healthy motivation shows CR value of 2,629 with probability equal to 0.009 . CR value of 2.629 greater than 1.656 and a probability smaller than 0.05 explains that people have a significant (real) effect on healthy motivation.

The estimation parameter for testing the effect of the product on the patient's decision shows CR value of 1,556 with probability equal to 0,120 . A CR value of 1.556 smaller than 1.656 and a probability greater than 0.05 indicates that the product has no significant effect on the patient's decision. The estimation parameter for testing the effect of the physical evidence on the patient's decision shows CR value of 1.326 with a probability of 0.185 . A CR value of 1.326 smaller than 1.656 and a probability greater than 0.05 explains that physical evidence has no significant effect on the patient's decision. The estimation parameter for testing the influence of people on the patient's decision shows CR value of 0.609 with a probability of 0,543 . CR value of 0.609 is smaller than 1.656 and probability greater than 0.05 explains that people have no significant effect on the patient decision. The estimation parameter for testing the influence of healthy motivation on the patient's decision shows CR value of 2,005 with probability equal to 0,045 . CR value of 2.005 greater than 1.656 and a probability smaller than 0.05 explains that healthy motivation has a significant effect on the patient's decision.

From the results of the analysis that has been done in this study can be concluded that to improve the variable decision of the patient then that must be done by the management the Cardiovascular Harapan Kita Hospital-Indonesia is more motivate patients to be healthy by creating a sense of security and comfort for Weekend Service the Cardiovascular Harapan Kita Hospital-Indonesia patients who treated, convince patients that by seeking treatment the Cardiovascular Harapan Kita Hospital-Indonesia higher healing rate and health status of patients will be better. This can be done through education and health promotion both in the conventional way (lectures, brochures, leaflets, etc) and non-conventional (the application of 
scientific marketing programs, white paper, webinar, etc.) to the community, especially the target patient Weekend Service that they Who have the ability to pay and those who tend to choose a hospital abroad for the maintenance of health. The Cardiovascular Harapan Kita Hospital-Indonesia should also always strive to maintain the patient's trust in the Cardiovascular Harapan Kita Hospital-Indonesia's reputation as the best hospital in handling heart disease. As for improving the patient's healthy motivation, the first priority scale must be done is to build the physical evident variable through the dimensions of important evidence by improving facilities and infrastructure, maintaining the legal and certification elements that have been achieved both KARS accreditation and JCI, and other dimensions of evidence by adding publication-publication of the Cardiovascular Harapan Kita Hospital-Indonesia in national and international media. The second is to maintain and improve the skills, education, and knowledge of the officers, whether doctors, nurses, support personnel, administrators and frontline officers. The third is to maintain the quality of service products through the dimensions of reliability by providing services that are proficient, nimble and timely, dimensions of responsiveness by providing fast and responsive service, the dimension of certainty by providing appropriate and precise service, the empathy dimension by providing a sincere and full-service attention.

The results of data processing shown in Table 4 can be concluded that the overall full model is an acceptable model fit. Thus the fundamental hypothesis of SEM analysis in this study is accepted which means that there is no significant difference between the covariance matrix of the observed variable and the covariance matrix of the implied covariance matrix. This shows that the structural equation produced by the fit model (full model) in this research can be used to explain the relationship and influence between exogenous variables with endogenous variables. In other words, the results show that the model used is acceptable. The significance level of 0.052 shows as a model of a good structural equation as it is still above the limit value. Measurement indexes of TLI, CFI, CMIN / DF and RMSEA are within the expected value range even though GFI and AGFI are received marginally.

Tabel 4. Goodness of Fit Index

\begin{tabular}{|c|c|c|c|c|}
\hline No & Goodness of Fit Measure & Cut of Value & Result & Criteria \\
\hline 1 & DF & $>0$ & 128 & $\begin{array}{c}\text { Over } \\
\text { Identified }\end{array}$ \\
\hline & Chi Square $\left(\mathrm{x}^{2}\right)$ & $<\alpha . \mathrm{df}$ & 155,067 & \\
\hline 2 & Probability (p) & $\geq 0,05$ & 0,052 & Good Fit \\
\hline 3 & CMIN/DF & $<2$ & 1,211 & Good Fit \\
\hline 4 & Goodness of Fit Index (GFI) & $\mathrm{GFI} \geq 0.90$ & 0,891 & Marginal Fit \\
\hline
\end{tabular}


Adjusted Goodness of Fit Index (AGFI)

Comparative Fit Index (CFI)

Tucker-Lewis Index or Non-Normed Fit Index (TLI or NNFI)

Incremental Fit Index (IFI)

$$
\text { AGFI } \geq 0.90
$$

$$
\mathrm{CFI} \geq 0.90
$$

$\mathrm{NNFI} \geq 0.90$

0,957

IFI $\geq 0.90$

0,965

Good Fit

0,855

Marginal Fit

0,964

Good Fit

Good Fit

RMSEA $\leq 0.08$

0,040

Good Fit
Root Mean Square Approximation (RMSEA)
Error of

\section{Conclusions}

It can be concluded that product, physical evidence, people have an effect on healthy motivation. In addition to the product, physical evidence, people, only motivation affects the patient's health decisions. To obtain maximum results on the patient's decision to use the service Weekend Service of the Cardiovascular Harapan Kita Hospital-Indonesia, the thing that must be done is to provide motivation to the patient for his health by creating a sense of security and comfort for Weekend Service the Cardiovascular Harapan Kita Hospital-Indonesia patients who treated, convince patients that with treatment to the Cardiovascular Harapan Kita Hospital-Indonesia healing rate High and the health of patients will be better. This can be done through education and health promotion both in the conventional way (lectures, brochures, leaflets etc.) and non-conventional (the application of scientific marketing programs, white paper, webinar, etc.) to the community, especially the target patient Weekend Service that they Who have the ability to pay and those who tend to choose a hospital abroad for the maintenance of health. The Cardiovascular Harapan Kita Hospital-Indonesia should also always strive to maintain the patient's trust in the Cardiovascular Harapan Kita Hospital-Indonesia's reputation as the best hospital in handling heart disease. As for improving the patient's healthy motivation, the first priority scale must be done is to build the physical evident variable through the dimensions of important evidence by improving facilities and infrastructure, maintaining the legal and certification elements that have been achieved both KARS accreditation and JCI, and other dimensions of evidence by adding publication -publication of the Cardiovascular Harapan Kita Hospital-Indonesia in national and international media. The second is to maintain and improve the skills, education, and knowledge of the officers, whether doctors, nurses, support personnel, administrators and frontline officers. The third is to maintain the quality of service products through the dimensions of reliability by providing services that are proficient, nimble and timely, dimensions of responsiveness by providing fast and responsive service, the dimension of certainty by providing appropriate and precise service, the empathy dimension by providing a sincere and full-service attention. 


\section{References}

Armen, A., Sefnedi \& Yuhelmi. (2013). Pengaruh bauran pemasaran jasa, keluarga dan motivasi terhadap keputusan pemilihan SMK Negeri 1 Kota Sungai Penuh. Abstrak dan Atikel Prodi PSP2K, 3(2).

Hurriyati, R. (2010). Bauran Pemasaran dan Loyalitas Konsumen. Alfabeta. Jakarta

Kotler, P., \& Keller, K. L. (2012). Marketing Management. New Jersey: Pearson Prentice Hall, Inc.

Kotler, P. (2002). Manajemen Pemasaran. New Jersey: Hall International, Inc.

Kotler, P., \& Amstrong, G. (1996). Dasar-Dasar Pemasaran, Edisi V, jilid 2, Intermedia, Jakarta.

Lupiyoadi, R., \& Hamdani, A. (2006). Manajemen Pemasaran Jasa. Edisi Kedua. Salemba Empat. Jakarta.

Motwani, D., Shrimali, D., \& Agarwal, K. (2014). Customers attitude towards social media marketing. Blue Ocean Research Journal, 3(4).

Oktawinanda, R., Kamela, I., \& Yuhelmi. (2013). The influence of the marketing mix, motivation, and attitude of consumers against purchasing decision Mobile Samsung Android at Padang.

Sarianti, R., \& Atris. (2013). Pengaruh Bauran Pemasaran terhadap Keputusan pembelian. Kajian Manajemen Bisnis, 2(1), 7-12.

Schiffman, L. G., \& Kanuk, L. L. (2007). Consumer Behavior (9th ed.). Pearson Prentice Hall. New Jersey.

Undang-Undang Republik Indonesia Nomor 23 Tahun 1992 Tentang Kesehatan.

Zarchi, M. R., Jabbari, A., Rahimi, H., Shafaghat, T., \& Abbasi, S. (2014). Preparation and designing a checklist for health care marketing mix with medical tourism approach. International Journal of Travel Medicine \& Global Health, 1(3), 103-108.

\section{Copyrights}

Copyright for this article is retained by the author(s), with first publication rights granted to the journal.

This is an open-access article distributed under the terms and conditions of the Creative Commons Attribution license (http://creativecommons.org/licenses/by/4.0/) 